\title{
Article \\ Effects of the COVID-19 Pandemic on Indoor Air Quality and Thermal Comfort of Primary Schools in Winter in a Mediterranean Climate
}

\author{
Alicia Alonso ${ }^{1, *}{ }^{\mathbb{C}}$, Jesús Llanos ${ }^{2}$, Rocío Escandón ${ }^{1}\left[\mathbb{D}\right.$ and Juan J. Sendra ${ }^{1} \mathbb{C}$ \\ 1 Instituto de Arquitectura y Ciencias de la Construcción, Escuela Técnica Superior de Arquitectura, \\ Universidad de Sevilla, 41012 Sevilla, Spain; rescandon@us.es (R.E.); jsendra@us.es (J.J.S.) \\ 2 Escuela Técnica Superior de Arquitectura, Universidad de Sevilla, 41012 Sevilla, Spain; jesllajim@alum.us.es \\ * Correspondence: aliciaalonso@us.es
}

Citation: Alonso, A.; Llanos, J.; Escandón, R.; Sendra, J.J. Effects of the COVID-19 Pandemic on Indoor Air Quality and Thermal Comfort of Primary Schools in Winter in a Mediterranean Climate. Sustainability 2021, 13, 2699. https://doi.org/ $10.3390 /$ su13052699

Academic Editor: Paola Villoria-Sáez

Received: 5 February 2021

Accepted: 26 February 2021

Published: 3 March 2021

Publisher's Note: MDPI stays neutral with regard to jurisdictional claims in published maps and institutional affiliations.

Copyright: (c) 2021 by the authors. Licensee MDPI, Basel, Switzerland. This article is an open access article distributed under the terms and conditions of the Creative Commons Attribution (CC BY) license (https:// creativecommons.org/licenses/by/ $4.0 /)$.

\begin{abstract}
Research studies have shown the potential effects of indoor environmental quality (IEQ) on pupils' health and academic performance. The COVID-19 pandemic has prompted renewed interest in the assessment of deficient indoor air quality (IAQ) conditions in schools and has become a priority over achieving adequate comfort conditions. Scientific studies confirm aerosols as one of the transmission routes of SARS-CoV-2 so that the possibility of airborne transmission increases in indoor environments with high occupancy, such as classrooms. As a result, international protocols and guidelines have established a requirement for educational buildings to over-ventilate with a fresh outdoor air supply. The main object of this work is to analyse the effects of the COVID-19 pandemic on thermal comfort and indoor air quality, in winter, in two classrooms of southern Spain. Thus, onsite measurements of environmental variables were conducted before and during the pandemic. Both classrooms have mechanical ventilation systems as they are within a recently built primary school (2018). Results shows a decrease of $300 \mathrm{ppm}$ in $\mathrm{CO}_{2}$ weekly average values during the pandemic, when hybrid ventilation is used, and a decrease of $400 \mathrm{ppm}$ when schools are naturally ventilated during all teaching hours. However, the analysis of standards shows that over $60 \%$ of hours are thermal discomfort conditions.
\end{abstract}

Keywords: COVID-19; IAQ; children's school; thermal comfort; IEQ; Mediterranean climate; manual airing

\section{Introduction}

In recent years, there have been many studies on indoor environmental quality (IEQ) in schools in different countries and climatic areas. The scientific literature has widely analysed the vulnerability of students to indoor environmental conditions in high-occupancy spaces and its potential effect on pupils' health and wellbeing [1-3], as well as on the learning process and academic performance [4-6]. A guideline book was also published to describe the optimal design and operation of schools with respect to low energy cost and performance of students, focusing on healthy indoor environment among other aspects [7].

Most of these studies, several of which took place in the Mediterranean climate, reported frequent deficiencies in indoor environmental conditions [8,9], mainly the indoor air quality (IAQ), resulting from inadequate or misused ventilation systems [10-12]. The study by Campano et al. [8] concluded that heating did not lead to widespread complaints as the occupants' mean thermal sensation (TSV) in classrooms in a Mediterranean climate is that of thermal neutrality during winter, and slight warmth during mid-seasons. In this regard, the school environment must be homogeneously clean, safe, and comfortable in order to reduce exposure to chemical and biological agents, prevent diseases, facilitate cognitive development, and avoid unequal educational outcomes [13]. D'Ambrossio Alfano et al. [14] developed other study that should be mentioned, in which there are 
also wider thermal comfort analyses over a large sample of students (4000) carried out in Mediterranean Countries, such as Italy. The study concluded that the Fanger's basic approach for the assessment of the thermal comfort is also effective in naturally ventilated environments if a right expectancy factor is known.

In spite of this, neither the public nor private administration has focused special attention on the IAQ of schools, and more surprisingly, it has also been neglected by the educational community and parents' associations. $\mathrm{CO}_{2}$ is a good bio-effluents indicator, and it could be correlated with the ventilation of a room, therefore, its concentration rate is used as the main indicator of IAQ [15] and to determine the ventilation rate in occupied spaces [16] such as schools. However, if the levels of pollution are higher outside than indoors, $\mathrm{CO}_{2}$ does not indicate indoor pollutants with health risk [17]. Except for a few studies, the monitoring of $\mathrm{CO}_{2}$ levels in classrooms and the relationship of these levels to the use of ventilation systems have barely been studied [18]. Furthermore, it has also not been verified whether the average level of $1000 \mathrm{ppm}$, recommended by some international documents and standards [19-21], has been exceeded.

The COVID-19 pandemic, declared by the World Health Organisation (WHO) on 11 March 2020, has prompted renewed interest in the assessment of deficient IEQ conditions in school classrooms, mainly indoor air quality and thermal comfort, making it necessary to completely modify how educational spaces are ventilated. Based on the findings of different studies, the transmissibility of COVID-19 can be influenced by airflow, as well as by environmental conditions. Recently, research has pinpointed aerosols as one of the transmission routes of SARS-CoV-2 [22] so that airborne transmission in indoor environments is highly likely [23].

In March 2020, school closures were implemented worldwide as a measure for preventing the spread of COVID-19. The repercussions of this preventive measure on educational and social development, wellbeing, and mental health were negative [24,25]. Although it has been concluded that the reopening of schools has not led to significant outbreaks or increased risk [26,27], some studies established that a return to the classroom must be accompanied by large-scale Test, Trace, and Isolate (TTI) systems [28] in order to prevent new waves.

Recent research and international guidelines published for schools' reopening $[25,29]$ have determined the need to implement effective measures to minimise the risk of transmission, including an interpersonal distance of $2 \mathrm{~m}$, face masks, frequent hygiene, temperature checks, and improved ventilation $[23,24,30]$. According to results, natural, hybrid, and mechanical ventilation systems can be used effectively and safely in schools, removing contaminated indoor air and supplying fresh outdoor air [26]. This preventive measure, along with the addition of filters, is a primary solution for the control of infectious diseases [31,32] and reduction of potential transmission [33]. However, not all ventilation strategies are acceptable and those which rely on centralised air distribution and/or recirculation create optimum conditions for the rapid spread of disease [16].

According to several authors, the recommended rates established in standards [34,35], 4-6 air change hours (ACH) for classrooms [29] and a relative humidity (RH) of 40-60\%, may be low in pandemic conditions [32].

The problem of poor environmental conditions is especially serious in classrooms of schools in countries with a Mediterranean climate, including Spain, as most schools rely on the manual opening of windows as the only ventilation system to try to achieve good IAQ [10], which is expected to worsen in the climate change scenarios forecast [36]. Increasing outside air fractions in a Mediterranean climate entails a rise of total air change rates, but it may also lead to higher energy consumption. This is probably one of the main reasons why approximately 8000 educational establishments in the school building stock of the Mediterranean area do not have mechanical ventilation systems [37], even though Spanish regulations specify the need for this type of ventilation so that IAQ is classed as "IDA 2", category of IAQ $\left(\mathrm{CO}_{2}\right.$ level of $500 \mathrm{ppm}$ additional to the outdoor air concentration), requiring a ventilation flow of $0.0125 \mathrm{~m}^{3} / \mathrm{s}$ per occupant [38]. 
In this regard, in adverse weather conditions, the widespread use of manual airing does not usually guarantee a decreased health risk of spreading airborne diseases and outdoor air pollution, nor does it ensure the conditions of thermal comfort and energy consumption. Research carried out by Stabile et al. in Italian schools, which rely predominantly on manual airing, provides information on the incompatibility between hygrothermal comfort and the IAQ of classrooms in winter conditions [39]. The effect of some ventilation strategies on indoor air quality and heating consumption in classrooms is also analysed, with the presence of energy-deficient thermal envelopes also affecting the situation [40]. Thus, in order to maintain hygrothermal comfort [41], a balance should be struck by ensuring manual airing during breaks, thus reducing $\mathrm{CO}_{2}$ levels without altering the thermal comfort of pupils [42].

Before the COVID-19 pandemic, achieving adequate comfort conditions was considered a priority over ensuring an adequate IAQ. However, currently, for winter 2020-2021, protocols and guidelines for classroom ventilation have been established in Spain [43,44], even with a clear decrease in the recommended limit values for $\mathrm{CO}_{2}$ levels (Figure 1). Although existing guidelines do not follow a systematic approach when defining measures, they prioritise guaranteeing IAQ in order to ensure the greatest possible prevention of transmission, reducing anything that might significantly affect not only hygrothermal comfort conditions but also pupils' health.

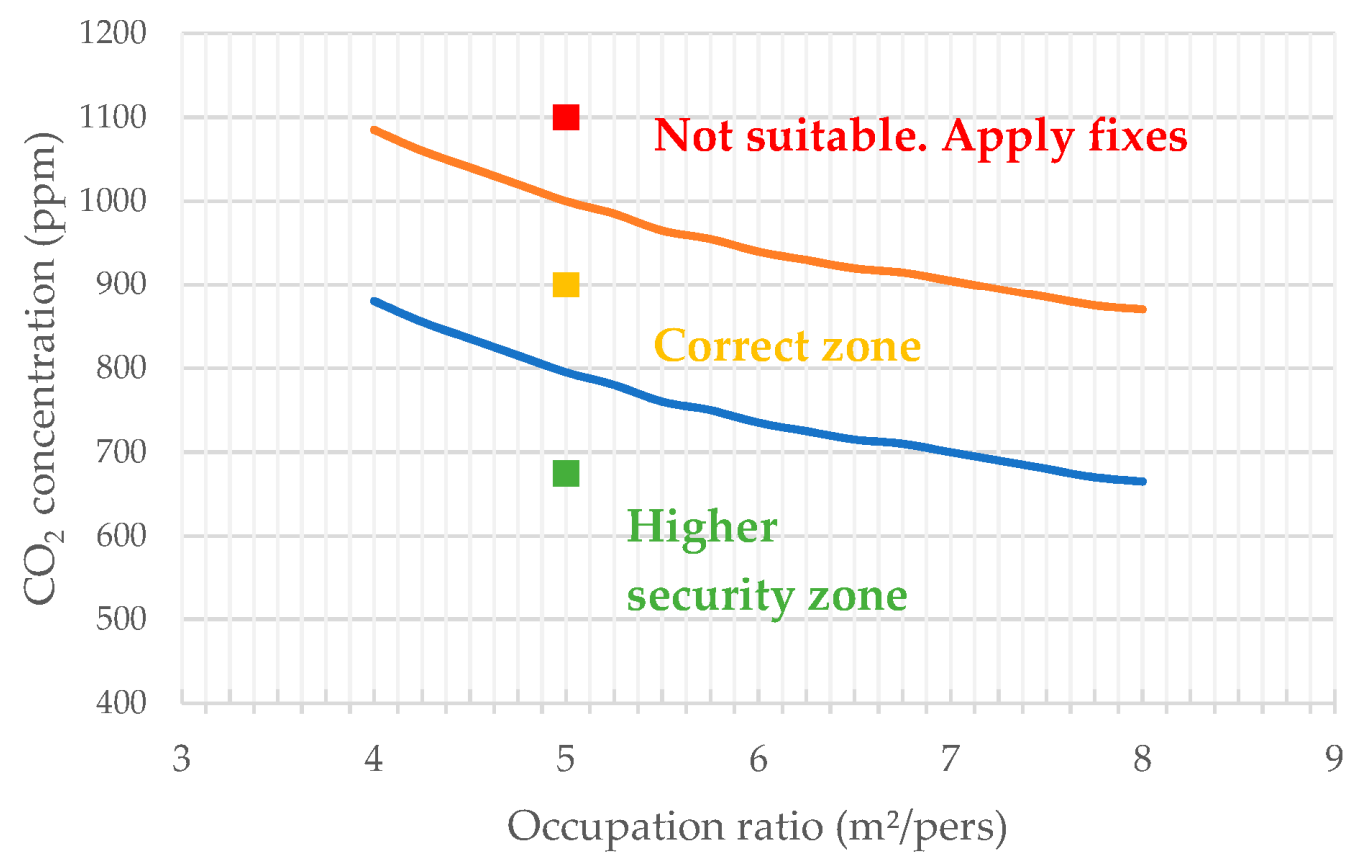

Figure 1. Maximum recommended $\mathrm{CO}_{2}$ concentration in a classroom based on occupancy (considering 450 ppm of $\mathrm{CO}_{2}$ in outdoor air). Blue line: maximum recommended values. Red line: limit values that should not be exceeded at any time [43].

Conditions of vulnerability are especially pronounced in pre-schools and primary schools $[45,46]$, due to the age of the potential students: 4 to 6 years of age in the former and 6 to 12 in the latter. Avoiding crowded, poorly ventilated classrooms is a requirement for the safe and healthy return of most pupils to school [29,47]. The implementation of a system of hygrothermal conditions and IAQ monitoring (air temperature (ta), $\mathrm{RH}, \mathrm{CO}_{2}$ ), together with other interventions, is conditional on the success of not exceeding acceptable limits [24].

Going to schools is an essential activity for children and young students, so it is important to analyse pupils' thermal comfort and IAQ conditions of classrooms. It should also be noted the social significance that IEQ, manifested by the media, has had in the classrooms of schools during this year of pandemic. The main objective of this work is to analyse the 
monitored indoor environmental conditions in winter for two classrooms in southern Spain. Having had the opportunity to monitor the environmental variables of a primary school just before the pandemic, the results presented for this study are for January 2020, before the pandemic, and for December-January 2021, during the pandemic. These classrooms incorporate a mechanical ventilation system, as they are in a recently built pre-school (2018). However, under normal conditions of use (prior to the pandemic), it used both natural and mechanical ventilation, depending on the external environmental conditions.

\section{Materials and Methods}

The research methodology carried out starts with the implementation of a system of thermal comfort and IAQ monitoring, which measured environmental parameters during the normal operation of teaching activities for a period of 13 weeks in winter before and during the COVID-19 pandemic. The selected case study is made up of two representative classrooms of a pre-school located in southern Spain (Mediterranean climate).

In order to obtain results and analyse the hygrothermal and air quality conditions and effects of the pandemic on the selected case study, the methodological process was set out as follows:

- Selection and characterisation of case study,

- Development of monitoring campaign,

- Data collection: use of heating, ventilation, and air conditioning (HVAC), ventilation protocols, thermal comfort, and IAQ parameters.

\subsection{Characterisation of the Case Study}

The pre-school selected in this study is located in Seville, which is classified as B4 following the Spanish energy performance zoning and is one of the most representative climatic areas in the south of Spain. Different areas in the region of Andalusia, including Seville, are covered according to the Köppen climate classification [48]. Zone B4 is characterised by hot-summer Mediterranean climate (Köppen CSa), with temperatures above $22{ }^{\circ} \mathrm{C}$, and cold to temperate areas in winter, with minimum temperatures usually remaining above $0{ }^{\circ} \mathrm{C}$.

The recent construction date (2018) and the strict regulations in place justify the suitable thermal characteristics of the building envelope (Table 1), whose thermal transmittance (U) values comply with the limit established [49]. In addition, this school has mechanical ventilation systems, mandatory in Spain since 2007, but lacking in most of the school building stock of the Mediterranean [35], due to its high cost, energy consumption, and demanding maintenance regime. The school is located in the East of Seville, next to a large green area, which contributes to the low level of outdoor air pollution.

The two classrooms selected are located on the second floor of the building and they are geometrically identical, but with opposing orientation: one is south facing (A5), while the other faces north (A6). In addition, although both have a large floor-to-ceiling window onto a courtyard, the position of the windows on the facade differs. Although both classrooms have a mechanical ventilation system, regarding manual airing through windows, only A5 can provide cross-ventilation while A6 only provides ventilation from one side. Figure 2 shows images of the building and one of the classrooms analysed in this study. Table 2 collects occupancy patterns, air rate, thermal loads, and other HVAC information of interest. 
Table 1. Classroom envelope composition and thermal transmittance value (U).

\begin{tabular}{|c|c|c|c|c|}
\hline Element & Composition & $\begin{array}{c}\text { Thermal Transmittance } \\
\qquad \mathrm{U}\left(\mathrm{W} /\left(\mathrm{m}^{2} \mathrm{~K}\right)\right)\end{array}$ & $\begin{array}{c}\text { U Limits } \\
\left(\mathbf{W} /\left(\mathbf{m}^{2} \mathbf{K}\right)\right)[49]\end{array}$ & $\begin{array}{c}\text { Thickness } \\
\text { (cm) }\end{array}$ \\
\hline Facade & $\begin{array}{l}\text { Concrete prefabricated panel }(16 \mathrm{~cm}) \text {, air chamber } \\
\text { of variable thickness, self-supporting framework } \\
\text { with reinforced plasterboard panels }(15+15 \mathrm{~mm}) \\
\text { and mineral wool insulation }(40 \mathrm{~mm}) .\end{array}$ & 0.57 & 1 & 27 \\
\hline Windows & $\begin{array}{l}\text { Aluminium frame (Class } 2 \text { air permeability, Class } \\
6 \text { A watertightness, and wind resistance Class C2). } \\
\text { (A5, A6) Floor-to-ceiling windows of laminated } \\
\text { safety glass }(6+6 \mathrm{~mm}) \text {. (A5) Sliding } \\
\text { windows-insulated glass units }(4+12+6 \mathrm{~mm}) \text {. }\end{array}$ & 4.06 & 4.2 & - \\
\hline Roof & $\begin{array}{l}\text { Reinforced concrete slab (35-40 cm high) and } \\
\text { lightweight concrete blocks. False ceiling: air } \\
\text { chamber, mineral wool insulation }(20 \mathrm{~mm}) \text {, and } \\
\text { plasterboard panel }(13 \mathrm{~mm}) \text {. Non-transitable roof } \\
\text { covering with precast concrete flooring }\end{array}$ & 0.37 & 0.65 & $100-120$ \\
\hline
\end{tabular}
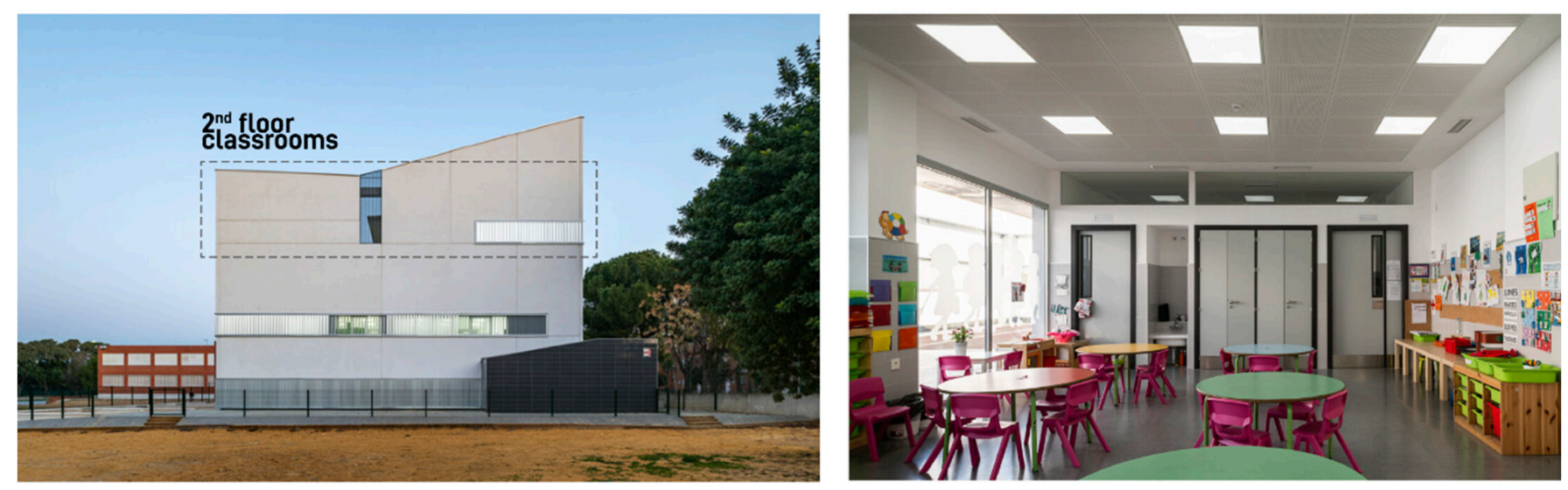

Figure 2. Images of the building and one of the classrooms.

Table 2. Classroom characteristics.

\begin{tabular}{|c|c|c|}
\hline Parameter & South Class (A5) & North Class (A6) \\
\hline Area & $105.30 \mathrm{~m}^{2}$ & $100.15 \mathrm{~m}^{2}$ \\
\hline$\%$ of gaps in the envelope & $30.6 \%$ & $22.7 \%$ \\
\hline Envelope gap characteristics & \multicolumn{2}{|c|}{ Class 2 air permeability. $\mathrm{U}=4.06 \mathrm{~W} / \mathrm{m}^{2} \cdot \mathrm{K}$} \\
\hline Occupation Profile & \multicolumn{2}{|c|}{25 5-year-old children +1 teacher } \\
\hline Occupation ratio & $4.05 \mathrm{~m}^{2} /$ person & $3.85 \mathrm{~m}^{2} /$ person \\
\hline Hours of occupation & \multicolumn{2}{|c|}{ 9:00-14:00 h } \\
\hline \multicolumn{3}{|c|}{ Required IAQ category: “IDA 2" } \\
\hline \multirow[t]{2}{*}{ HVAC * systems } & $\begin{array}{r}\text { Mechanical ventil } \\
\text { Discharg }\end{array}$ & $\begin{array}{l}-50 \% \text { of efficiency) } \\
\text { lassroom) }\end{array}$ \\
\hline & \multicolumn{2}{|c|}{$\begin{array}{l}\text { Variable Refrigerant Volume system (VRV) } \\
\text { Outdoor Unit: Heat Pump } \\
\text { Indoor Unit: Duct Fancoil }\end{array}$} \\
\hline
\end{tabular}

\footnotetext{
${ }^{*}$ Heating, Ventilation and Air Conditioning.
} 
Figure 3 shows the floor distribution, the position of monitoring devices, and a distribution scheme of HVAC facilities in the two classrooms. The ventilation system is predominantly solved by a mixed air HVAC system (Figure 3), with VRV (Variable Refrigerant Volume) direct expansion equipment for hot/cold thermal treatment. Therefore, a heat pump is used for thermal production and sensible heat recovery equipment for the mechanical ventilation system, scheduled to operate during occupied hours. The IAQ established in this building is categorised as "IDA 2" [38] with a $\mathrm{CO}_{2}$ level of $500 \mathrm{ppm}$ in addition to the outdoor air concentration, requiring a $0.0125 \mathrm{~m}^{3} / \mathrm{s}$ ventilation flow per occupant.

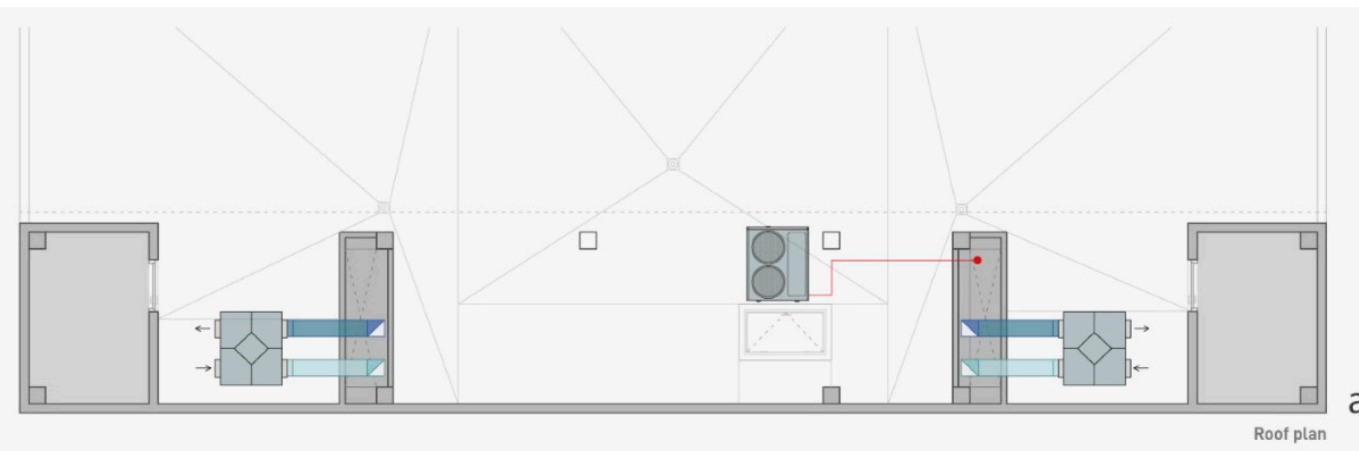

a)

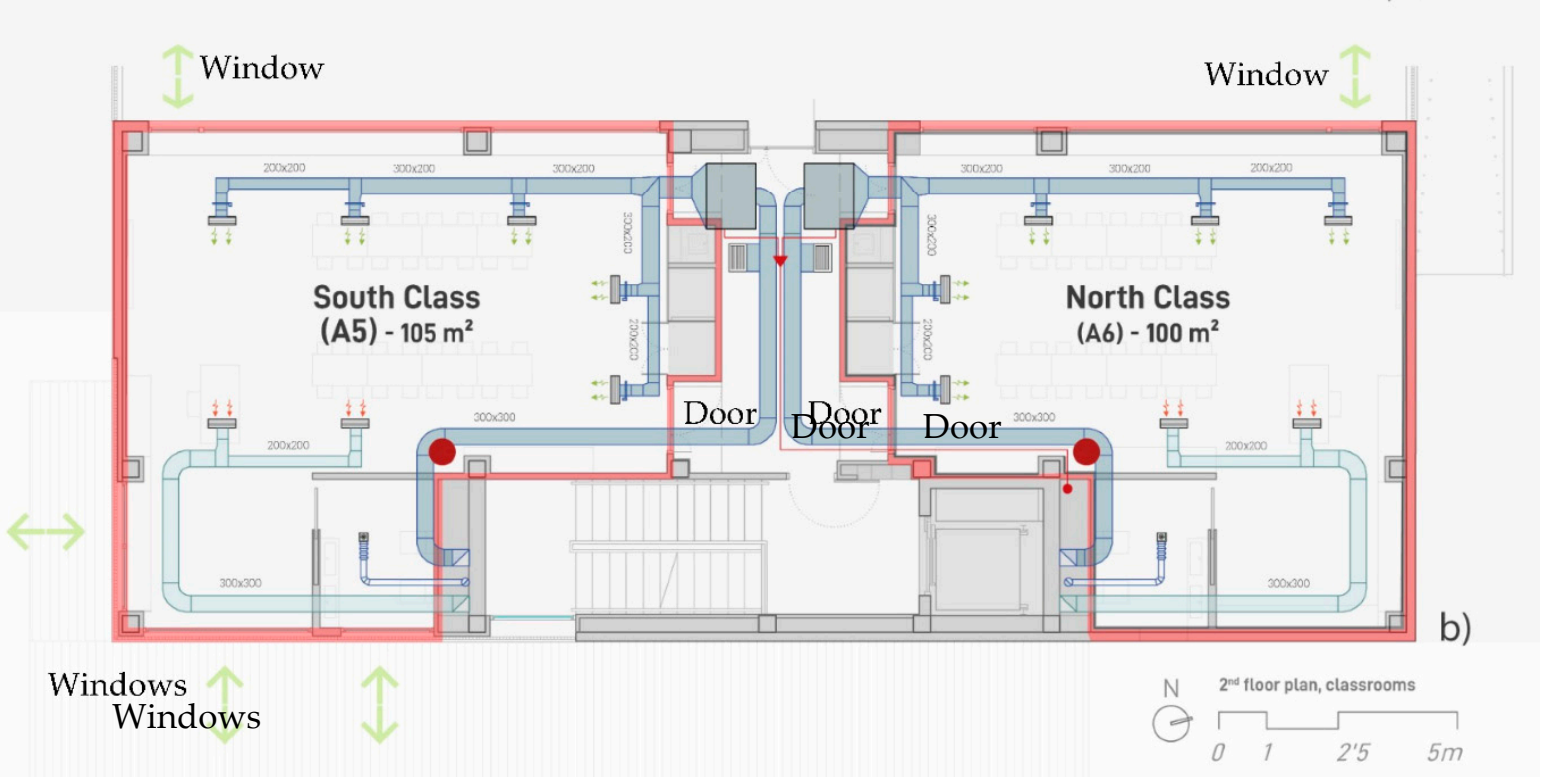

Figure 3. Plans of case studies with a distribution scheme of heating, ventilation, and air conditioning (HVAC) facilities in the two classrooms (red points show the position of monitoring devices): (a) roof plan, (b) floor plan.

\subsection{Monitoring}

The database is established from onsite measurements of the environmental conditions of air temperature, relative humidity, and level of $\mathrm{CO}_{2}$ concentration. The monitoring device used was the Wöhler CDL 210 logger and data collection was configured to take measurements at $30 \mathrm{~min}$ intervals. Table 3 summarises the characteristics of the equipment and sensors used in the measurement.

As shown in Figure 3, monitoring devices were placed at a height of approximately $1.5 \mathrm{~m}$, along the interior perimeter of the classroom away from direct solar radiation and air currents to avoid distortions in the data collection without hampering teaching activity. It was located in a representative point where users can have control and perception of the temperature, taking into account the importance of making these criteria compatible with the conditions of use of a space occupied by children. 
Table 3. Characteristics of the measuring equipment.

\begin{tabular}{ccccc}
\hline & \multicolumn{2}{c}{ CDL 210 Wöhler Data Logger } & \\
Parameter & Units & Limit Range & Accuracy & Measuring Interval \\
\hline $\mathrm{CO}_{2}$ concentration & $\mathrm{Ppm}$ & $0-6000$ & $50( \pm 5 \%)$ & \\
Air temperature (ta) & ${ }^{\circ} \mathrm{C}$ & $-10-60$ & \pm 0.6 & $15 \mathrm{~min}$ \\
Relative humidity $(\mathrm{RH})$ & $\%$ & $5-95$ & \pm 3 & \\
\hline
\end{tabular}

Data for thermal effects were recorded over approximately 13 weeks in winter. An analysis of results will be carried out for two periods, before and during the COVID-19 pandemic, during which schools modified the ventilation patterns following the established protocols and guidelines.

The periods correspond to the following dates:

- Period 1: From 23 January to 13 March 2020, the last day of face-to-face teaching activity before the lockdown imposed due to the COVID-19 pandemic. In total, this 7 -week period is the equivalent of 35 school days.

- $\quad$ Period 2: From 30 November 2020 to 22 January 2021. In total, this 6-week period is the equivalent of 25 school days, including the Christmas holidays.

\subsection{Thermal Comfort Analysis}

To evaluate the effect of over-ventilation in thermal conditions, the comparative analysis is complemented with objective assessment of thermal comfort level by establishing parameters according to the thermal sensation experienced by humans. In accordance with recommendations of different methods and standards, thermal comfort models, both static (RITE and ISO 7730) [37,50] and adaptive (ASHRAE 55 and EN 16798) were analysed $[10,51,52]$. This task was carried out using different data, such as environmental parameter measurements, metabolic rate, and/or insulation clothing level. As stated by D'Ambrossio Alfano et al. [53], the predicted mean vote (PMV) model requires the knowledge of four thermohygrometic parameters (air temperature, radiant temperature, air velocity, and relative humidity). Limitations of this study promoted by the haste and urgency of reproducing the situation of the pandemic led to determine an approximation of the model through comfort temperature bands.

According to the current Spanish regulations [38], thermal comfort is defined as an operative temperature range of $21-23{ }^{\circ} \mathrm{C}$ in winter. When applying the method detailed in ISO 7730 [50], the metabolic rate value considered was 1.40, met for 5-year-old children, with a clothing insulation value of 1 clo for the winter period, based on the clothing worn by the occupants, and quantified according to Section A.4 of the ISO 7730 document. The thermal environment category selected was "B", which implies a Predicted Percentage of Dissatisfied (PPD) below 10\%.

The adaptive model defined in standard EN 16,798 [51] is applicable only to buildings where occupants perform low metabolic rate activities and can easily access operable windows and freely adapt clothing according to thermal conditions. In this study, a normal level of expectation (Cat. II level) is used, corresponding to a PPD $<10 \%$ and an acceptability range around the optimum comfort temperature of $\pm 3{ }^{\circ} \mathrm{C}$.

Regarding ASHRAE Standard 55 [20], this method is also applied in buildings used for low metabolic rate activity. For this analysis, the range considered is $90 \%$ of occupant acceptability (PPD $<10 \%$ ) (Cat. I level), so that an interval of $\pm 2.5^{\circ} \mathrm{C}$ around the optimum comfort temperature is applied.

\section{Results and Discussion}

For the analysis of the monitoring results, data collection corresponding to holidays and non-school days have been removed, while daily measurement data focused on the occupation interval, ensuring minimal distortion of the results. 
For this study, a representative monitoring week from winter period 1 (before the COVID-19 pandemic) from 23 January to 27 January 2020 was selected. It should be noted that during the pandemic, the issue of classroom air quality was considered a priority over thermal comfort. During a first stage of this period (December 2020), manual airing was mandatory at all times due to COVID-19 protocol and teachers were not authorised to activate the air conditioning systems, so that the level of clothing of the users was higher than usual. However, a sharp drop in temperatures in January 2021 led to a change in control protocols and teachers were granted official permission to control the air conditioning equipment. Therefore, in the case of period 2, the week selected for this research was that from 11 January to 15 January 2021 (control of HVAC systems). However, monitoring results were also analysed between 30 November and 4 December 2020 (no control of HVAC systems). A form was filled out by the teachers of each classroom and ventilation protocols used in each period analysed (before and during the pandemic) were indicated. Table 4 summarises the information on the HVAC protocols used in each classroom, during each period.

Table 4. HVAC protocols in each period.

\begin{tabular}{|c|c|c|c|}
\hline \multicolumn{4}{|c|}{ HVAC Protocols } \\
\hline Manual airing & Mechanical ventilation and heating & & \\
\hline No manual airing & Mechanical ventilation + heating & South Class (A5) & Period 1 \\
\hline No manual airing & 7:30 a.m. to 2:00 p.m. & North Class (A6) & \\
\hline Manual airing (cross) & Mechanical ventilation + heating & & \\
\hline 9:00 a.m. to 2:00 p.m. & 7:30 a.m. to 2:00 p.m. & South Class (A5) & Period 2a \\
\hline Manual airing (one window) & No mechanical ventilation, only heating & North Class (A6) & \\
\hline 11:30 a.m. to 2:00 p.m. & 7:30 a.m. to 2:00 p.m. & & \\
\hline $\begin{array}{l}\text { Manual airing (cross) } \\
\text { 7:30 a.m. to 2:00 p.m. }\end{array}$ & Neither mechanical ventilation nor heating & South Class (A5) & Period 2b \\
\hline $\begin{array}{l}\text { Manual airing (one window) } \\
\text { 7:30 a.m. to 2:00 p.m. }\end{array}$ & Neither mechanical ventilation nor heating & North Class (A6) & December 2020 \\
\hline
\end{tabular}

\subsection{Thermal Environment Evaluation}

In this section, the evolution of hygrothermal conditions before and during the COVID19 pandemic is analysed, assessing the impact of the variation of the ventilation protocols on users' thermal comfort. The evaluation takes into consideration the percentage of weekly hours in discomfort, both adaptive and static, for each standard analysed in this study.

In light of the results, during period 1, HVAC systems were continuously switched on during the occupation interval and classrooms were only ventilated mechanically, so that outdoor air was heated before being introduced into the classroom. This fact, together with internal loads produced by high density of occupation, results in temperatures of around $15^{\circ} \mathrm{C}$ in classrooms at the beginning of the teaching day, but reaching a maximum of almost $30^{\circ} \mathrm{C}, 12^{\circ} \mathrm{C}$ above the maximum outdoor temperature. In this regard, a variation of more than $12{ }^{\circ} \mathrm{C}$ in indoor temperature was observed in A5 (south) (Figure 4), as higher solar gains were obtained during the central hours of the day.

In period 2, the heating was in operation during all the occupied hours and the ventilation protocol is hybrid, so that classrooms were naturally ventilated during a percentage of the occupied hours. In this case, indoor temperatures always remained below $24{ }^{\circ} \mathrm{C}$, with indoor variations around $7{ }^{\circ} \mathrm{C}$, and a difference of $8^{\circ} \mathrm{C}$ above the maximum outdoor temperature. This is the result of the low outdoor temperatures, with a mean value of around $7{ }^{\circ} \mathrm{C}$ throughout the week. Higher temperature oscillations were observed in period 1 than in period 2 also due to a dissipation of the thermal loads when the windows were open. It should also be noted that, in both cases, the maximum outdoor temperature was lower than the indoor temperature as the heating was in operation. However, as the average indoor temperature was excessively high during period 1, in the south-facing classroom (A5), this affected the analysis of the comfort conditions. 


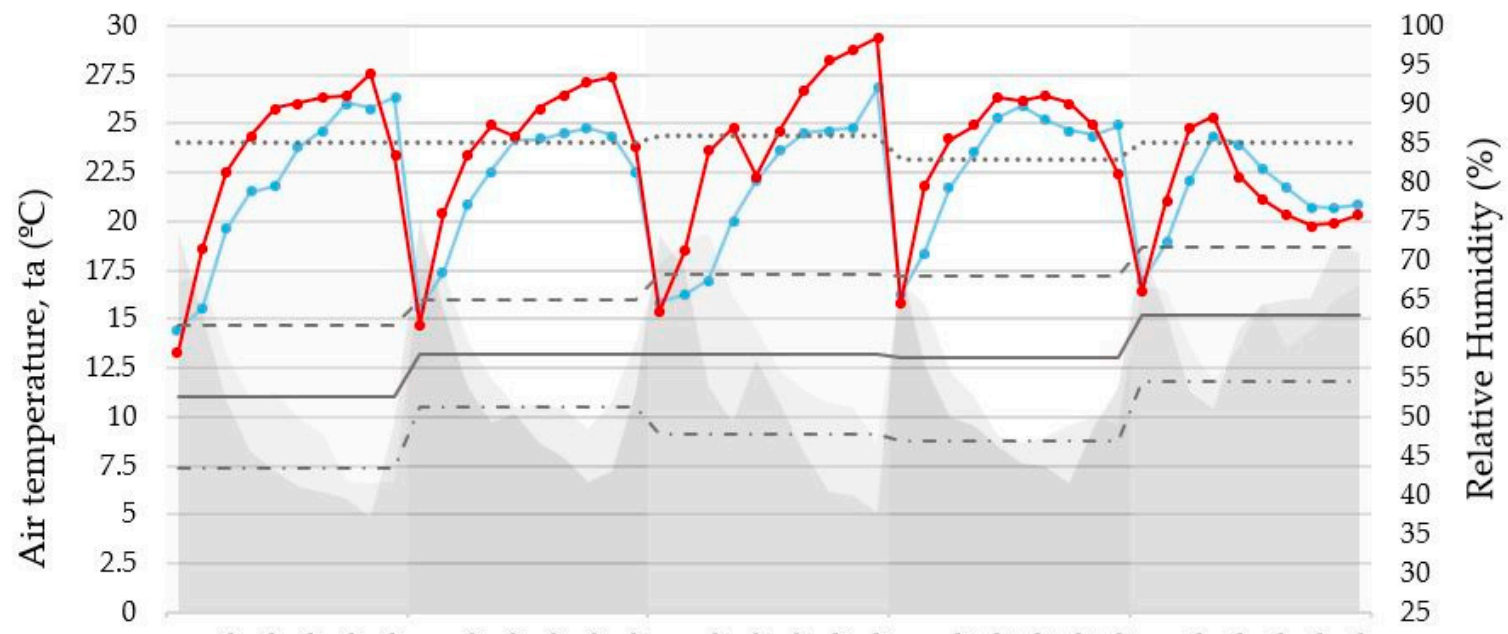

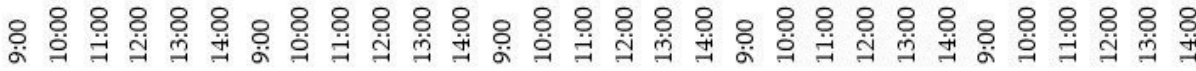

$$
\begin{gathered}
28 / 01 / 2020 \quad 29 / 01 / 2020 \quad 30 / 01 / 2020 \quad 31 / 01 / 2020 \\
\text { Data collection time (hh:mm) }
\end{gathered}
$$

\section{Data collection time (hh:mm)}

Relative Humidity_A6.N (Period 1$)$

—_ Temperature_A6.N (Period 1)

- - - Temperature max outdoor (Peiod 1)

-. - - Temperature min outdoor (Peiod 1)
Relative Humidity_A5.S (Period 1)

$\longrightarrow$ Temperature_A5.S (Period 1)

Temperature med outdoor (Peiod 1)

Relative Humidity outdoor (Period 1)

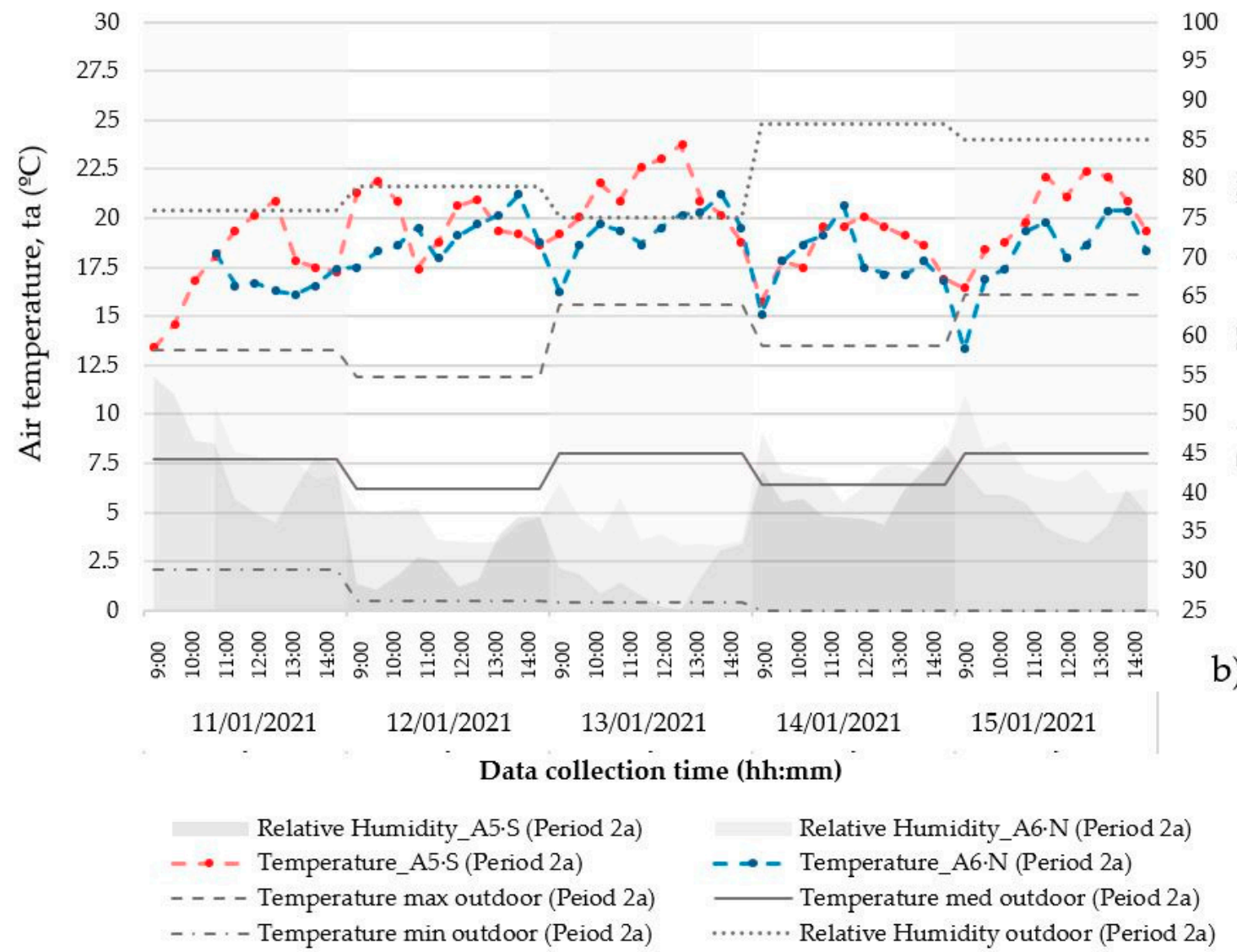

Figure 4. Comparison of the evolution of hygrothermal conditions between the periods monitored: (a) period 1, January 2020, before the COVID-19 pandemic, and (b) period 2a, January 2021, during the COVID-19 pandemic. 
As expected, the evolution of hygrothermal conditions (Figure 4) was influenced by the classroom orientation, so that maximum temperature values in A5 (south) were around $2.5{ }^{\circ} \mathrm{C}$ higher than in A6 (north). The comparative study shown in Figure 5 and Table 5 determines a higher total percentage of discomfort hours in A5 (south) during period 1, which was above $40 \%$ in all the standards analysed. In this case, a large percentage of discomfort sensation occurred when the upper temperature limit (Figure 5) was exceeded, which is unusual during winter. In case of A6 (north), the addition of manual airing entails a decrease in indoor temperatures, a more pronounced reduction in the north orientation (A6), so that the total of discomfort hours not reaching the lower temperature limit is $100 \%$ (RITE) [38] and exceeds 70\% (ISO 7730) [50]. It is interesting to note that discomfort values are doubled or even tripled (A6) when percentages of weekly hours below the lower threshold of the comfort band are analysed (Table 5).

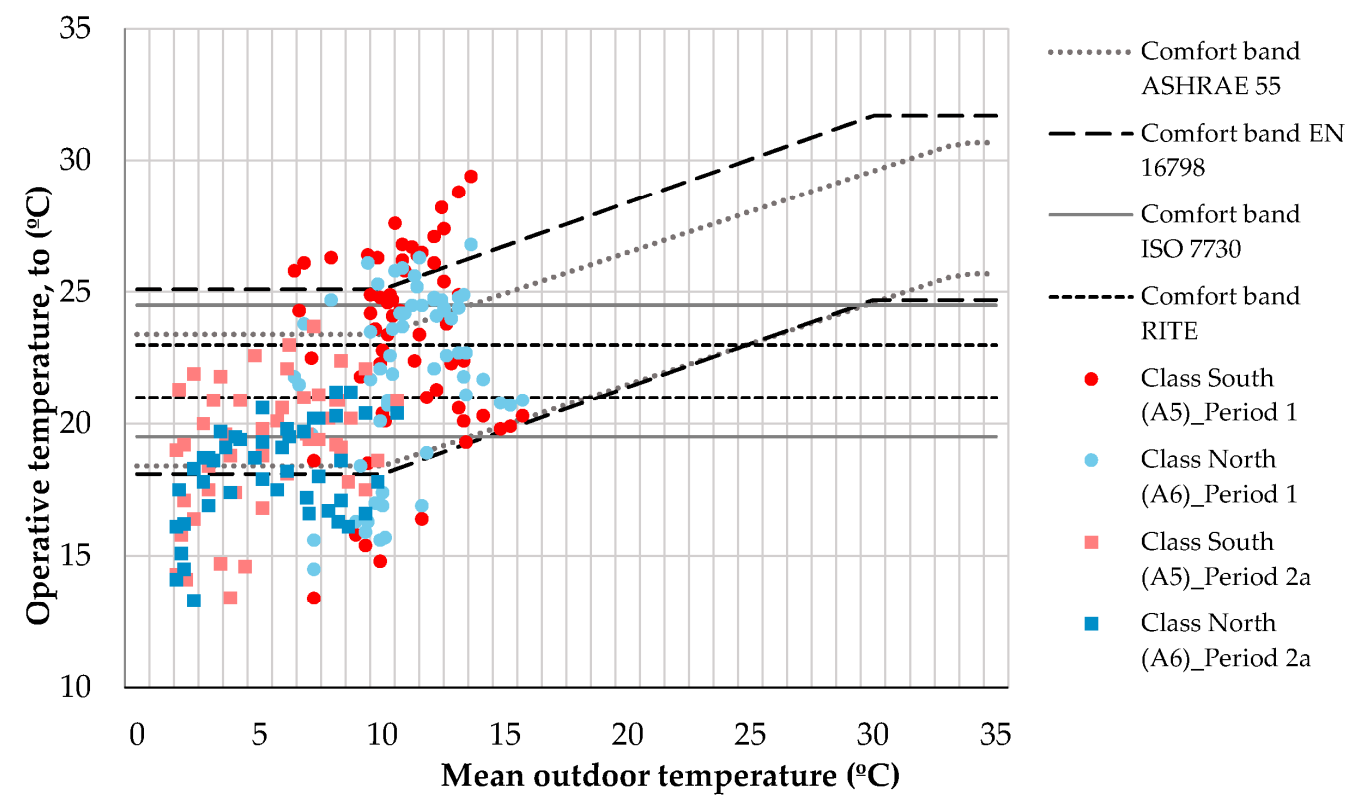

Figure 5. Comparison of thermal comfort evaluation between the monitoring periods (in this investigation, air temperature $(\mathrm{ta})=$ radiant temperature $(\mathrm{tr})=$ operative temperature $($ to $)$ has been assumed).

Table 5. Evaluation of thermal comfort standards.

\begin{tabular}{|c|c|c|c|c|c|c|c|c|c|}
\hline \multirow[b]{2}{*}{ Space } & \multirow[b]{2}{*}{$\begin{array}{l}\text { Monitoring } \\
\text { Periods }\end{array}$} & \multicolumn{2}{|c|}{$\begin{array}{l}\text { ASHRAE 55:2017 CAT I } \\
\left(\text { PPD }^{*} 10 \%\right) \text { [20] }\end{array}$} & \multicolumn{2}{|c|}{$\begin{array}{l}\text { EN 16798-1:2020 CAT II } \\
\text { (PPD* 10\%) [51] } \\
\text { Percentage of Weekl }\end{array}$} & \multicolumn{2}{|c|}{ RITE 2007 [38] } & \multicolumn{2}{|c|}{$\begin{array}{l}\text { ISO 7730:2005 CAT B } \\
\text { (PPD 10\%) [50] }\end{array}$} \\
\hline & & $\begin{array}{l}\text { Below Lower } \\
\text { Limit }\end{array}$ & Total & $\begin{array}{l}\text { Percentage } \\
\text { Below Lower } \\
\text { Limit }\end{array}$ & $\begin{array}{l}\text { Weekly } \\
\text { Total }\end{array}$ & $\begin{array}{l}\text { ours in Discom } \\
\text { Below Lower } \\
\text { Limit }\end{array}$ & Total & $\begin{array}{c}\text { Below Lower } \\
\text { Limit }\end{array}$ & Total \\
\hline \multirow{2}{*}{ South(A5) } & 1 & $17 \%$ & $63 \%$ & $13 \%$ & $43 \%$ & $30 \%$ & 93 & $17 \%$ & $60 \%$ \\
\hline & $2 a$ & & $27 \%$ & $24 \%$ & $20^{\circ}$ & & & & $40 \%$ \\
\hline \multirow{2}{*}{ North(A6) } & 1 & $23 \%$ & $53 \%$ & $20 \%$ & $30 \%$ & $30 \%$ & 77 & $23 \%$ & $53 \%$ \\
\hline & $2 a$ & $56 \%$ & $47 \%$ & $48 \%$ & $40 \%$ & $100 \%$ & $83 \%$ & $76 \%$ & $63 \%$ \\
\hline
\end{tabular}

* Predicted Percentage of Dissatisfied (\%).

On a standalone basis, it is also interesting to evaluate the evolution of ta and $\mathrm{RH}$ as well as the thermal comfort during a specific stage of period 2 in which no heating systems were in use and IAQ was an absolute priority over thermal comfort in order to minimise the spread of SARS-CoV-2. Following the guidelines published by the Consejo Superior de Investigaciones Científicas (CSIC) and Asociación Técnica Española de Climatización y Refrigeración (ATECYR) [42,43], manual airing of classrooms was mandatory regardless of outdoor conditions. Results monitored in A5 (south) in December 2020 are presented in Figure 6. It should be noted that teachers are not allowed to activate the air conditioning systems and classrooms are naturally ventilated at all times. The evolution of indoor 
temperature observed is significantly low and remains within the outdoor temperature range. In this regard, although outdoor temperatures are similar to those in period 1 (Figure 4), the average indoor temperature during period 2 is $6{ }^{\circ} \mathrm{C}$ lower than in period 1 . Therefore, the percentage of weekly hours in discomfort is $99 \%$ in all the models evaluated, as indoor temperature does not reach the lower limit of the comfort band.

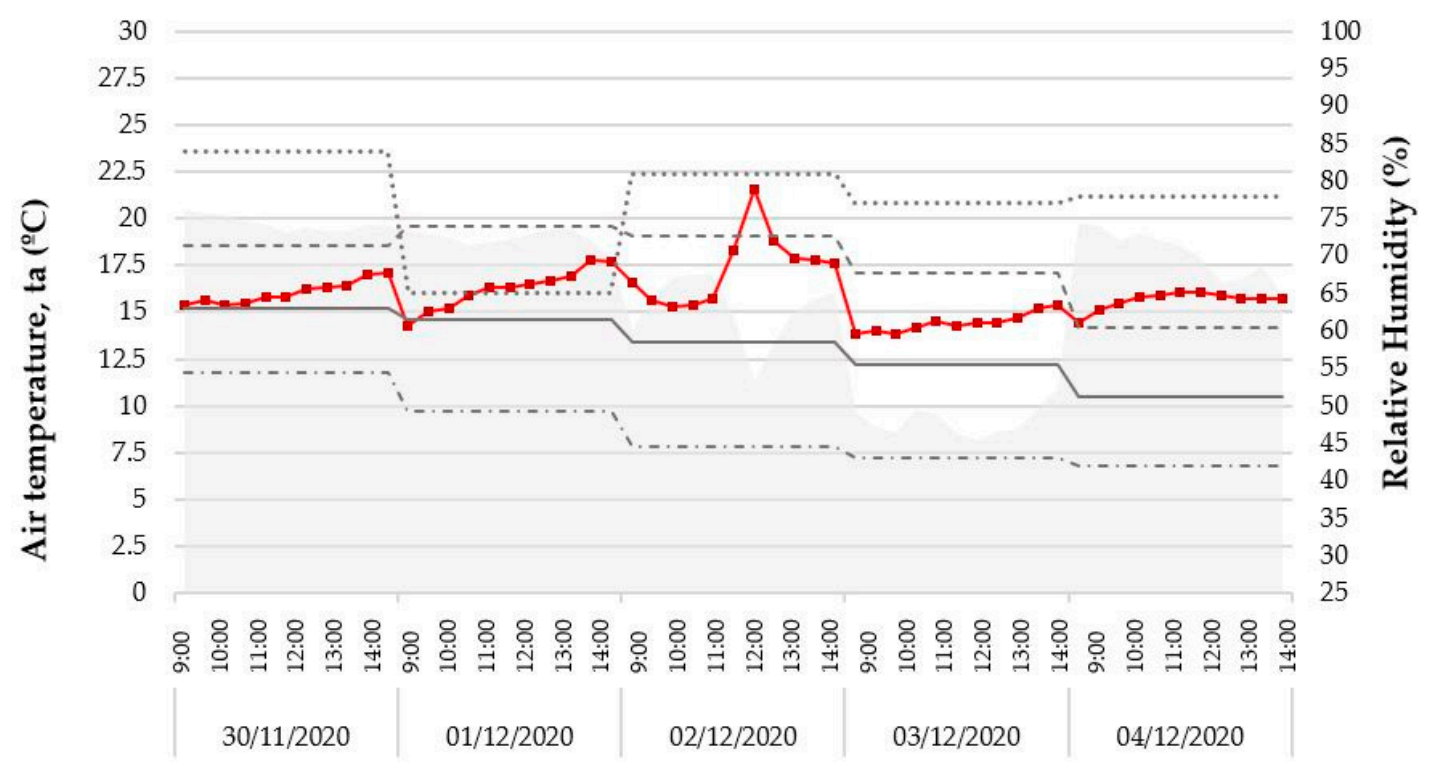

Data collection time (hh:mm)
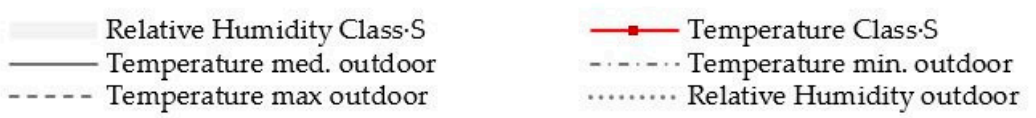

(a)

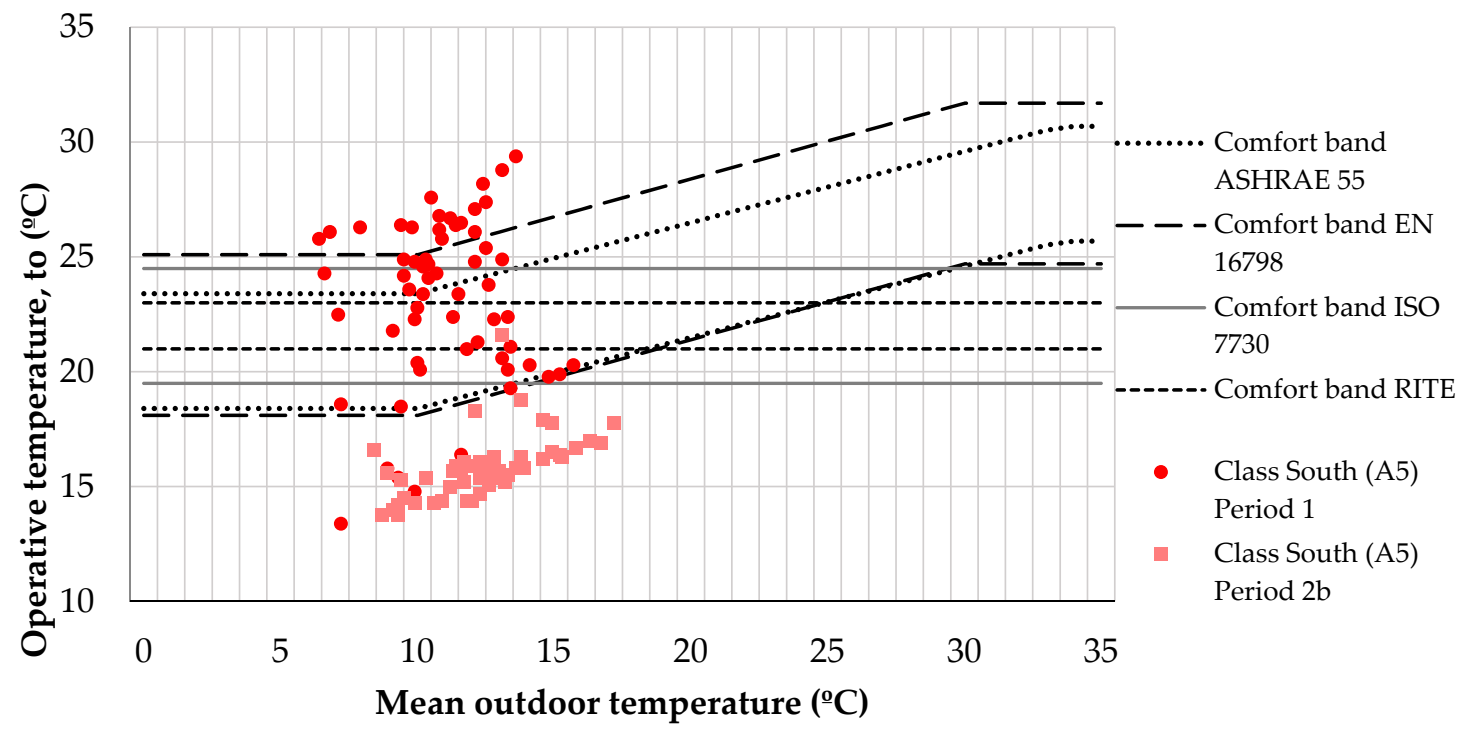

(b)

Figure 6. Results monitored in period 2, December 2021, during the COVID-19 pandemic: (a) Evolution of hygrothermal conditions, and (b) thermal comfort evaluation (in this investigation, $\operatorname{ta}=\operatorname{tr}=$ to has been assumed). 


\subsection{Indoor Air Quality Evaluation}

It is important to mention the variation of the requirements before and during the COVID-19 pandemic in terms of IAQ. During period 1, there were no specific ventilation protocols, and windows were opened and closed arbitrarily to suit user preferences. The required IAQ was "IDA 2" [38], a $\mathrm{CO}_{2}$ level of $500 \mathrm{ppm}$ additional to the outdoor air concentration, estimated to be $400 \mathrm{ppm}$ in this case study. In period 2, under pandemic conditions, the situation changed drastically and protocols for manual airing were too demanding since IAQ was an absolute priority to ensure heath conditions. In this regard, it was required to comply with stricter rates. The $\mathrm{CO}_{2}$ concentration ranges in both monitoring periods are shown in Figure 7 , together with the guideline values recommended for classroom ventilation $[42,43]$ to minimise the spread of the virus in the classrooms. In addition, a daily average concentration of $1000 \mathrm{ppm}$ is also added as it is an internationally recognised indicator [19-21].

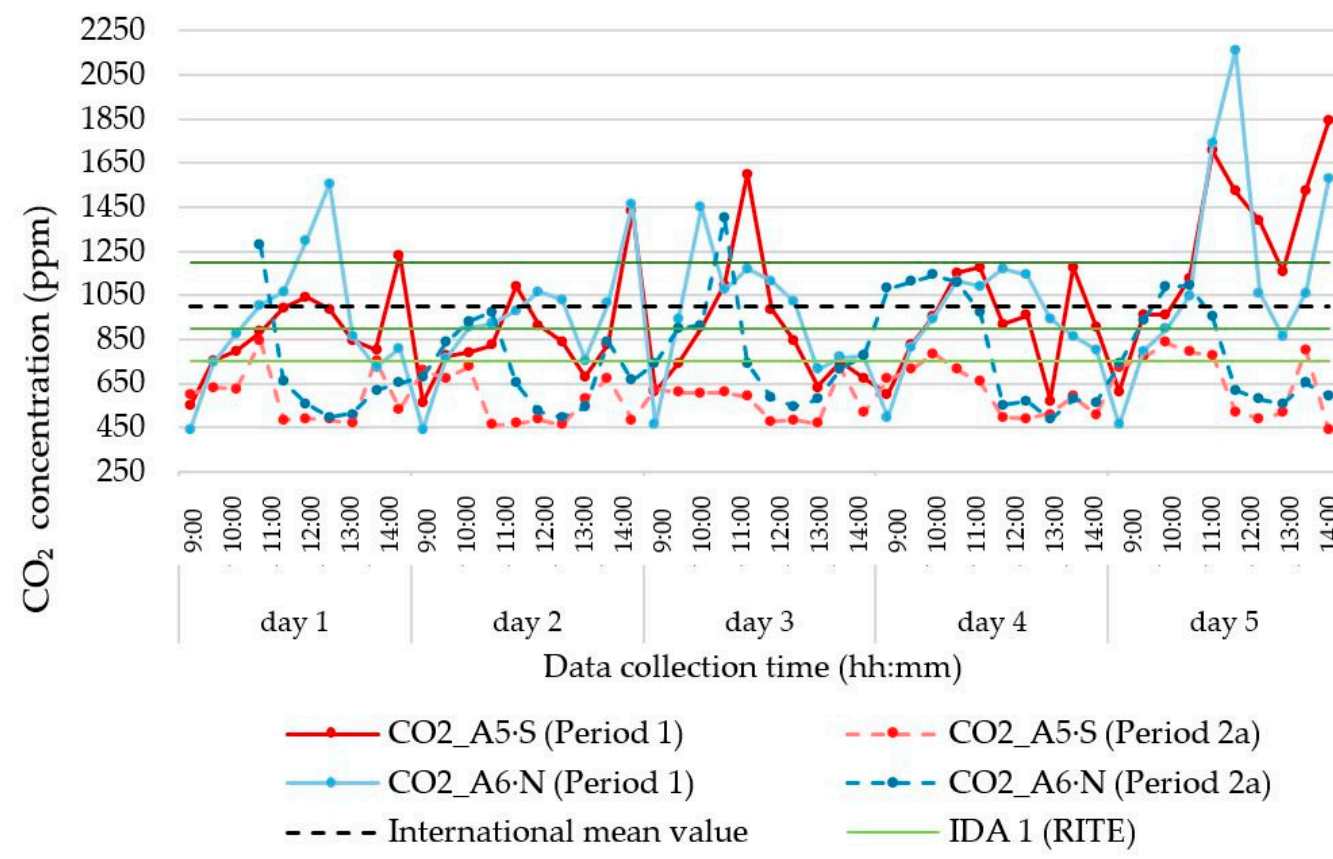

Figure 7. Comparison of the evolution of $\mathrm{CO}_{2}$ concentration between the monitoring periods (Period 1 and Period 2a).

In Figure 7, corresponding to period 1, this limit was exceeded in a large percentage of teaching hours in both classrooms, $48 \%$ of the $25 \mathrm{~h}$ per week in A5 (south) and $58 \%$ in A6 (north). This justified the use of the VRV system without activating the heat recovery units in order to avoid excessive consumption derived from low efficiency. In any case, the data monitored for the beginning of period 1 show that thermal comfort was prioritised over air renewal.

This was not the case during period 2, in which IAQ conditions, measured by $\mathrm{CO}_{2}$ concentration, were an absolute priority. In this case, the $\mathrm{CO}_{2}$ concentration value during $100 \%$ of the teaching hours in A5 was below the $1000 \mathrm{ppm}$ limit, and $86 \%$ of hours were even below the "IDA 1" limit [38]. However, in A6, 88\% and $72 \%$ of hours were recorded below $1000 \mathrm{ppm}$ and "IDA 1", respectively. Although these values continue to determine a significant improvement in IAQ compared to period 1, there was an increase in $\mathrm{CO}_{2}$ concentration in classroom A6 compared to $\mathrm{A} 5$. This is due to the deactivation of mechanical ventilation, as well as to the limitation of manual airing for fear of a drop in indoor temperatures.

Again, it is interesting to show the monitored $\mathrm{CO}_{2}$ values in December 2020 (period $2 b$ ) (Figure 8 ), when classrooms were naturally ventilated at all times. Compared to general protocol followed in winter in period 2a (January 2020), the decrease in $\mathrm{CO}_{2}$ concentration 
was more clearly perceptible during December 2020, and almost all the teaching hours registered values below the demanding limit determined by CSIS (2020) in guidelines published during the COVID-19 pandemic. Although the IAQ values are ideal, it was previously observed that the comfort conditions were not adequate, so that it was necessary to strike a balance between both conditions.

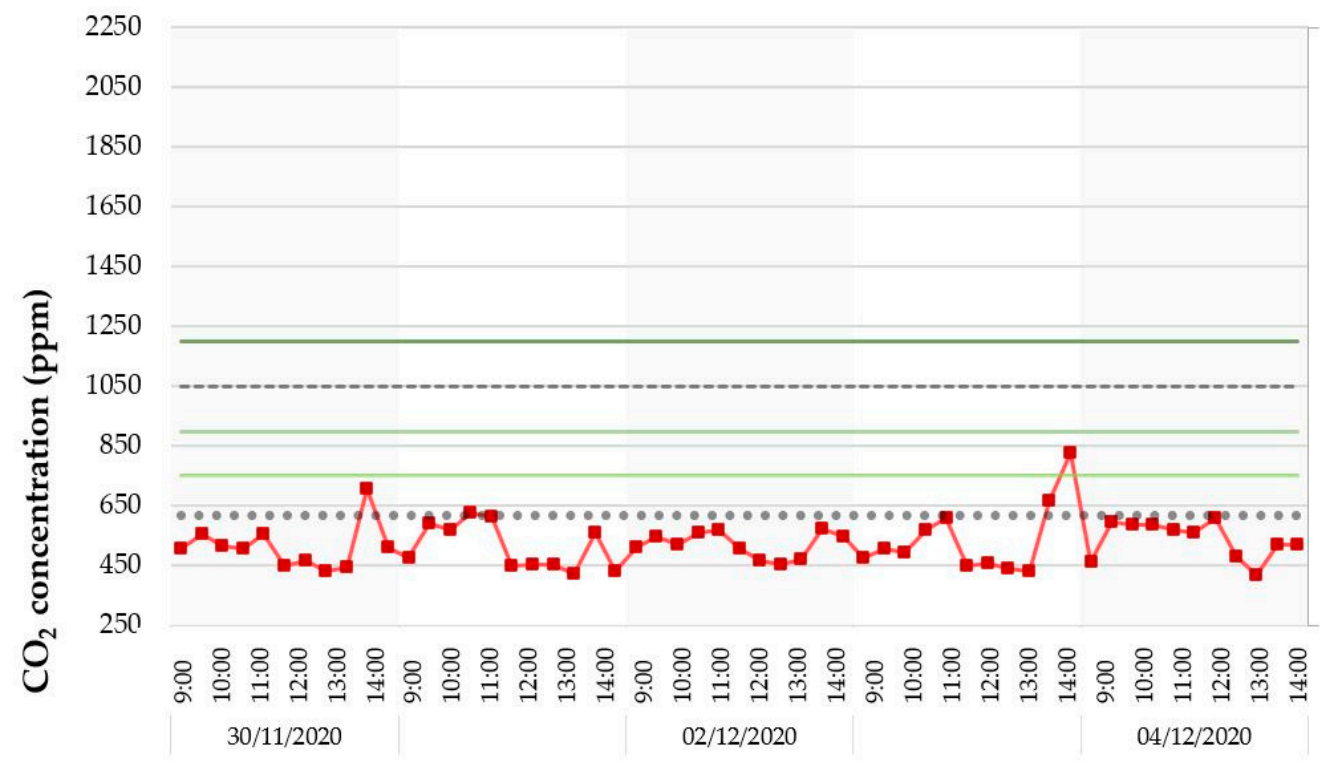

Data collection time (hh:mm)

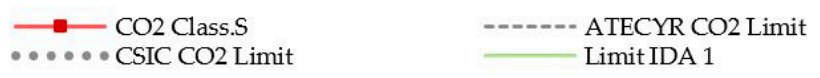

Figure 8. Evolution of $\mathrm{CO}_{2}$ concentration: period 2b, December 2020.

A summary of results of indoor measurements conducted in A5 and A6 is shown in Table 6. Outdoor values of temperature and relative humidity are also displayed. The effect of the COVID-19 pandemic on the indoor environmental quality in schools during the winter is highly positive in terms of IAQ conditions, with weekly average values around $600-750 \mathrm{ppm}$. It is interesting to note that maximum values of $\mathrm{CO}_{2}$ during period $2(780-110 \mathrm{ppm})$ were equal to or even lower than average values registered in period 1 (1000-1100 ppm). Nevertheless, the improvement of IAQ conditions in period 2 was not always accompanied by improved user thermal comfort, especially when the outdoor temperature was very low.

Table 6. Summary table of the results obtained under winter conditions.

\begin{tabular}{|c|c|c|c|c|c|c|c|c|c|c|}
\hline & & \multicolumn{3}{|c|}{$\mathrm{CO}_{2}(\mathrm{ppm})$} & \multicolumn{3}{|c|}{ Air Temperature $\left({ }^{\circ} \mathrm{C}\right)$} & \multicolumn{3}{|c|}{ Relative Humidity (\%) } \\
\hline & & Mean & Min. & Max. & Mean & Min. & Max. & Mean & Min. & Max. \\
\hline \multirow{3}{*}{ Period 1 (January 2020) } & Outdoor & - & - & - & 13 & 7.4 & 18.7 & 85.7 & 83 & 90 \\
\hline & South Class (A5) & 1033 & 618 & 1571 & 23.1 & 13.4 & 29.4 & 53.9 & 37.2 & 75.1 \\
\hline & North Class (A6) & 1079 & 530 & 1726 & 21.9 & 14.5 & 26.8 & 57.3 & 41.5 & 73.4 \\
\hline \multirow{3}{*}{ Period 2a (January 2021) } & Outdoor & - & - & - & 7 & 0 & 14 & 80.4 & 75 & 87 \\
\hline & South Class (A5) & 604 & 466 & 781 & 19 & 15 & 22 & 36.8 & 31.7 & 43.2 \\
\hline & North Class (A6) & 740 & 514 & 1177 & 18 & 14 & 20 & 40.9 & 37.4 & 47.2 \\
\hline
\end{tabular}

\section{Conclusions}

This study analysed the effects of the COVID-19 pandemic on thermal comfort and IAQ conditions in Mediterranean classrooms in the winter. Environmental variables such as temperature, humidity, and $\mathrm{CO}_{2}$ concentration levels were monitored before and during the pandemic. Under normal conditions of use, prior to the COVID-19 pandemic, 
the accomplishment of adequate thermal comfort in school buildings was prioritised over achieving better IAQ. This case study used both natural and mechanical ventilation, depending on the external environmental conditions. However, international ventilation protocols, guidelines, and IAQ requirements have changed significantly as a result of the pandemic, and a clear decrease has been established in the recommended limit values for $\mathrm{CO}_{2}$ levels. During the COVID-19 pandemic, it became mandatory to supply fresh air using manual airing, irrespective of outdoor conditions.

A new concern has arisen over the transmission of SARS-CoV-2, which has determined a special attention of IAQ and has led to the use of ventilation protocols based on only manual airing through windows. In this regard, the "emergency" ventilation protocols provide good results in terms of IAQ conditions, but not in relation to IEQ conditions, which are influenced by thermal comfort. It should be noted that this simple measure would not have been implemented had it not been for the existence of the pandemic.

Spanish regulations require a good IAQ category ("IDA 2", RITE) in educational buildings. In this study, from a more generic perspective, it was observed that the IAQ of both classrooms corresponded to a medium quality category ("IDA 3", RITE) [38] during period 1, with weekly average values around $1000 \mathrm{ppm}$, while during period 2a, IAQ was categorised as optimum ("IDA 1", RITE) [38], with weekly average values below 700 ppm.

The inadequate adjustment of a setpoint temperature higher than the recommended one led to a deterioration in thermal comfort during period 1. Although thermal comfort before the pandemic was not adequate, comfort conditions worsened during the pandemic, when IAQ was the main priority. During period 1, the total percentage of discomfort hours exceeded $50 \%$ for all the standards analysed, and even exceeding $60 \%$ in some cases, which is the upper temperature limit. In the case of period $2 b$, when classrooms were only naturally ventilated and only percentages of weekly hours under the lower limit of the comfort band were analysed, discomfort values doubled or even tripled, exceeding $80 \%$ in various models evaluated. Based on these results, in addition to mechanical ventilation, it would not have been necessary to provide manual airing during period 2a, since it could have led to unnecessary energy consumption.

Limitations of this study promoted by the haste and urgency of reproducing the situation of the pandemic led to determine an approximation of thermal models. Further analysis in terms of mean radiant and operative temperature should be conducted to represent thorough thermal comfort evaluation. In addition, further investigations are required to characterise the possibility of transmission of infections such as SARS-CoV-2, an in-depth analysis of airborne transmission such as computational fluid dynamics (CFD) assessment, or a full characterisation of airflows inside the classroom.

Author Contributions: Conceptualisation, A.A., J.J.S., J.L. and R.E.; methodology, J.L.; software, J.L.; validation, A.A., J.J.S., J.L. and R.E.; formal analysis, A.A., J.J.S. and J.L.; investigation, A.A., J.J.S. and J.L.; data curation, J.L.; writing-original draft preparation, A.A.; writing-review and editing, A.A., J.J.S., J.L. and R.E.; supervision, A.A., J.J.S. and R.E.; funding acquisition, A.A., J.J.S. and R.E. All authors have read and agreed to the published version of the manuscript.

Funding: This research was funded by Spanish Government, grant number IJC2018-035336-I, by European Social Fund, and by Regional Andalusian Government (Aid for the recruitment, incorporation of Research PhD Staff).

Institutional Review Board Statement: Not applicable.

Informed Consent Statement: Not applicable.

Data Availability Statement: Data available on request due to privacy restrictions. The data presented in this study are available on request from the corresponding author. The data are not publicly available due to privacy restrictions.

Conflicts of Interest: The authors declare no conflict of interest. 


$\begin{array}{ll}\text { Abbreviations } & \\ \text { Abbreviation } & \text { Nomenclature } \\ \text { ACH } & \text { Air Change Hour } \\ \text { CO2 } & \text { Dioxide of Carbon (ppm) } \\ \text { HVAC } & \text { Heating, Ventilation, and Air Conditioning } \\ \text { IAQ } & \text { Indoor Air Quality } \\ \text { IEQ } & \text { Indoor Environmental Quality } \\ \text { PPD } & \text { Predicted Percentage of Dissatisfied }(\%) \\ \text { PMV } & \text { Predicted Mean Vote } \\ \text { RH } & \text { Relative Humidity }(\%) \\ \text { ta } & \text { Air Temperature }\left({ }^{\circ} \mathrm{C}\right) \\ \text { to } & \text { Operative Temperature }\left({ }^{\circ} \mathrm{C}\right) \\ \text { tr } & \text { Radiant Temperature }\left({ }^{\circ} \mathrm{C}\right) \\ \text { TSV } & \text { Thermal Sensation Vote } \\ \text { TTI } & \text { Test Trace and Isolate } \\ \text { U } & \text { Thermal Transmittance }\left(\mathrm{W} /\left(\mathrm{m}^{2} \mathrm{~K}\right)\right. \\ \text { VRV } & \text { Variable Refrigerant Volume } \\ \text { WHO } & \text { World Health Organisation }\end{array}$

\section{References}

1. Yang, B.; Olofsson, T.; Wang, F.; Lu, W. Thermal comfort in primary school classrooms: A case study under subarctic climate area of Sweden. Build. Environ. 2018, 135, 237-245. [CrossRef]

2. Griffiths, M.; Eftekhari, M. Control of $\mathrm{CO}_{2}$ in a naturally ventilated classroom. Energy Build. 2008, 40, 556-560. [CrossRef]

3. Salthammer, T.; Uhde, E.; Schripp, T.; Schieweck, A.; Morawska, L.; Mazaheri, M.; Clifford, S.; He, C.; Buonanno, G.; Querol, X.; et al. Children's well-being at schools: Impact of climatic conditions and air pollution. Environ. Int. 2016, 94, 196-210. [CrossRef] [PubMed]

4. Shendell, D.G.; Prill, R.; Fisk, W.J.; Apte, M.G.; Blake, D.; Faulkner, D. Associations between classroom $\mathrm{CO}_{2}$ concentrations and student attendance in Washington and Idaho. Indoor Air 2004, 14, 333-341. [CrossRef]

5. Wargocki, P.; Wyon, D.P. Providing better thermal and air quality conditions in school classrooms would be cost-effective. Build Environ. 2013, 59, 581-589. [CrossRef]

6. Petersen, S.; Jensen, K.; Pedersen, A.; Rasmussen, $\mathrm{H}$. The effect of increased classroom ventilation rate indicated by reduced $\mathrm{CO}_{2}$ concentration on the performance of schoolwork by children. Indoor Air 2016, 26, 366-379. [CrossRef] [PubMed]

7. Alfano, F.R.D. (Ed.) Indoor Environment and Energy Efficiency in Schools; REHVA: Brussels, Belgium, 2010.

8. Campano, M.A.; Domínguez-Amarillo, S.; Fernández-Agüera, J.; Sendra, J.J. Thermal Perception in Mild Climate: Adaptive Thermal Models for Schools. Sustainability 2019, 11, 3948. [CrossRef]

9. De Giuli, V.; Da Pos, O.; De Carli, M. Indoor environmental quality and pupil perception in Italian primary schools. Build. Environ. 2012, 56, 335-345. [CrossRef]

10. Gennaro, G.; Dambruoso, P.R.; Loiotile, A.D.; Di Gilio, A.; Giungato, P.; Tutino, M.; Marzocca, A.; Mazzone, A.; Palmisani, J.; Porcelli, F. Indoor air quality in schools. Environ. Chem. Lett. 2014, 12, 467-482. [CrossRef]

11. Fernández-Agüera, J.; Campano, M.A.; Domínguez-Amarillo, S.; Acosta, I.; Sendra, J.J. $\mathrm{CO}_{2}$ Concentration and Occupants' Symptoms in Naturally Ventilated Schools in Mediterranean Climate. Buildings 2019, 9, 197. [CrossRef]

12. Dorizas, P.V.; Assimakopoulos, M.N.; Helmis, C.; Santamouris, M. An integrated evaluation study of the ventilation rate, the exposure and the indoor air quality in naturally ventilated classrooms in the Mediterranean region during spring. Sci. Total Environ. 2015, 502, 557-570. [CrossRef] [PubMed]

13. WHO. School Environment: Policies and Current Status; WHO Regional Office for Europe: Copenhagen, Denmark, 2015.

14. D'Ambrossio Alfano, F.R.; Ianniello, E.; Palella, B.I. PMV-PPD and acceptability in naturally ventilated schools. Build. Environ. 2013, 67, 129-137. [CrossRef]

15. Chatzidiakou, L.; Mumovic, D.; Summerfield, A. Is $\mathrm{CO}_{2}$ a good proxy for indoor air quality in classrooms? Part 1: The interrelationships between thermal conditions, $\mathrm{CO}_{2}$ levels, ventilation rates and selected indoor pollutants. Build. Serv. Eng. Technol. 2015, 36, 129-161. [CrossRef]

16. Lipinski, T.; Ahmad, D.; Serey, N.; Jouhara, H. Review of ventilation strategies to reduce the risk of disease transmission in high occupancy buildings. Int. J. Thermofluids 2020, 7-8, 100045. [CrossRef]

17. Pereira, P.F.; Ramos, N.M.M. The impact of mechanical ventilation operation strategies on indoor $\mathrm{CO}_{2}$ concentration and air exchange rates in residential buildings. Indoor Built Environ. 2020. [CrossRef]

18. Fisk, W.J. The ventilation problem in schools: Literature review. Indoor Air 2017, 27, 1039-1051. [CrossRef] [PubMed]

19. Building Bulletin 101. Guidelines on Ventilation, Thermal Comfort and Indoor Air Quality in Schools; Department for Education: London, UK, 2016. 
20. ASHRAE. Thermal Environmental Conditions for Human Occupancy; ASHRAE Standard 55-2017; American Society of Heating, Refrigerating and Air Conditioning Engineers: Atlanta, GA, USA, 2017.

21. AIR. Ausschuss für Innenraumrichtwerte (German Committee on Indoor Guide Values); German Federal Environment Agency: Dessau-Roßlau, Germany, 2019.

22. WHO. Modes of Transmission of Virus Causing Covid-19: Implications for Ipc Precaution Recommendations: Scientific Brief; World Health Organization: Geneva, Switzerland, 2020.

23. Noorimotlagh, Z.; Jaafarzadeh, N.; Martínez, S.S.; Mirzaee, S.A. A systematic review of possible airborne transmission of the COVID-19 virus (SARS-CoV-2) in the indoor air environment. Environ. Res. 2021, 193, 110612. [CrossRef] [PubMed]

24. Stage, H.B.; Shingleton, J.; Ghosh, S.; Scarabel, F.; Pellis, L.; Finnie, T. Shut and re-open: The role of schools in the spread of Covid-19 in Europe. medRxiv 2020. [CrossRef]

25. SickKids. COVID-19: Recommendations for School Reopening. 17 June 2020. Available online: https://www.sickkids. $\mathrm{ca} /$ siteassets/news/news-archive/2020/covid19-recommendations-for-school-reopening-sickkids-june.pdf (accessed on 29 July 2020).

26. Bonell, C.; Melendez-Torres, G.; Viner, R.M.; Rogers, M.B.; Whitworth, M.; Rutter, H.; Rubin, G.J.; Patton, G. An evidence-base theory of change for reducing SAR-CoV-2 transmission in reopened schools. Health Place 2020, 64, 102398. [CrossRef] [PubMed]

27. Public Health England. Weekly Coronavirus Disease 2019 (COVID-19) Surveillance Report; Public Health England: London, UK, 2020; Volume 25.

28. Panovska-Griffiths, J.; Kerr, C.C.; Stuart, R.M.; Mistry, D.; Klein, D.; Viner, R.M.; Bonell, C. Determining the optimal strategy for reopening schools, the impact of test and trace interventions, and the risk of occurrence of a second COVID-19 epidemic wave in the UK: A modelling study. Lancet Child Adolesc. Health 2020, 4, 817-827. [CrossRef]

29. Jones, E.; Young, A.; Clevenger, K.; Salimifard, P.; Wu, E.; Luna, M.L.; Lahvis, M.; Lang, J.; Bliss, M.; Azimi, P.; et al. Healthy Schools: Risk Reduction Strategies for Reopening Schools; Harvard, T.H., Ed.; Chan School of Public Health: Boston, MA, USA, 2020.

30. Tang, S.; Mao, Y.; Jones, R.M.; Tan, Q.; Ji, J.S.; Li, N.; Shen, J.; Lv, Y.; Pan, L.; Ding, P.; et al. Aerosol transmission of SARS-CoV-2? Evidence, prevention and control. Environ. Int. 2020, 144, 106039. [CrossRef]

31. Morawska, L.; Cao, J. Airborne transmission of SAR-CoV-2: The world should face the reality. Environ. Int. 2020, 139, 105730. [CrossRef]

32. Dielz, L.; Horve, P.F.; Coll, D.A.; Frez, M.; Elsen, J.A.; Van Den Wymelenberg, K. 2019 novel coronavirus (COVID-19) pandemic: Built environment considerations to reduce transmission. mSystems 2020, 5, e00375-20. [CrossRef]

33. Buonanno, G.; Stabile, L.; Morawska, L. Estimation of airborne viral emission: Quanta emission rate of SARS-CoV-2 for infection risk assessment. Environ. Int. 2020, 141, 105794. [CrossRef]

34. ASHRAE. Ventilation for Acceptable Indoor Air Quality, American Society of Heating, Refrigerating and Air-Conditioning Engineers ANSI/ASHRAE Standard 62.1-2019; American Society of Heating, Refrigerating and Air Conditioning Engineers: Atlanta, GA, USA, 2019.

35. Domínguez-Amarillo, S.; Fernández-Agüera, J.; González, M.M.; Cuerdo-Vilches, T. Overheating in Schools: Factors Determining Children's Perceptions of Overall Comfort Indoors. Sustainability 2020, 12, 5772. [CrossRef]

36. CEN. Ventilation for Non-Residential Buildings_-Performance Requirements for Ventilation and Room-Conditioning Systems; CEN-EN 13779:2008; Comité Européen de Normalisation: Brussels, Belgium, 2008.

37. ZEMeds. Promoting Renovation of Schools in a Mediterranean Climate up to Nearly Zero-Energy Buildings. 2016. Available online: http:/ / www.zemeds.eu/ (accessed on 4 January 2021).

38. RITE. Reglamento de Instalaciones Técnicas en Edificios (Regulation of Technical Installations in Buildings); Instituto para la Diversificación y Ahorro de la Energía: Madrid, Spain, 2007.

39. Stabile, L.; Massimo, A.; Canale, L.; Russi, A.; Andrade, A.; Dell'Isola, M. The effect of ventilation strategies on indoor air quality and energy consumptions in classrooms. Buildings 2019, 9, 110. [CrossRef]

40. Calama-González, C.M.; Suárez, R.; León-Rodríguez, A.L.; Ferrari, S. Assessment of Indoor Environmental Quality for Retrofitting Classrooms with An Egg-Crate Shading Device in A Hot Climate. Sustainability 2019, 11, 1078. [CrossRef]

41. Abrams, E.M.; McGill, G.; Bhopal, S.S.; Sinha, I.; Fernandes, R.M. COVID-19, asthma, and return to school. Lancet Respir Med. 2020, 8, 847-849. [CrossRef]

42. Korsavi, S.S.; Montazami, A.; Mumovic, D. Indoor air quality (IAQ) in naturally-ventilated primary schools in the UK: Occupantrelated factors. Build. Environ. 2020, 180, 106992. [CrossRef]

43. ATECYR. Acciones en Centros Educativos: Recomendaciones para la Mejora de la Ventilación en los Sistemas de Climatización y Saneamiento. (Actions in Educational Centres: Recommendations for Improving Ventilation in HVAC and Sanitation Systems); Asociación Técnica Española de Climatización y Refrigeración: Madrid, Spain, 2020.

44. CSIC. Guía para Ventilación en Aulas (Guidelines for Classroom Ventilation); Instituto de Diagnóstico Ambiental y Estudios del Agua, IDAEA-CSIC, Consejo Superior de Investigaciones Científicas: Barcelona, Spain, 2020.

45. Martinez-Molina, A.; Boarin, P.; Tort-Ausina, I.; Vivancos, J.L. Post-occupancy evaluation of a historic primary school in Spain: Comparing PMV, TSV and PD for teachers' and pupils' thermal comfort. Build. Environ. 2017, 117, 248-259. [CrossRef]

46. Almeida, S.M.; Canha, N.; Silva, A.; do Carmo Freitas, M.; Pegas, P.; Alves, C.; Pio, C.A. Children exposure to atmospheric particles in indoor of Lisbon primary schools. Atmos. Environ. 2011, 45, 7594-7599. [CrossRef] 
47. Chan, W.R.; Li, X.; Singer, B.C.; Pistochini, T.; Vernon, D.; Outcault, S.; Sanguinetti, A.; Modera, M. Ventilation rates in California classrooms: Why many recent HVAC retrofits are not delivering sufficient ventilation. Build. Environ. 2020, 167, 106426. [CrossRef]

48. Kottek, M.; Grieser, J.; Beck, C.; Rudolf, B.; Rubel, F. World Map of the Köppen-Geiger climate classification updated. Meteorol. Z. 2006, 15, 259-263. [CrossRef]

49. CTE. Código Técnico de la Edificación, Documento Básico de Ahorro de energía, Sección HE 1; Dirección General de Arquitectura, Vivienda y Suelo: Madrid, Spain, 2017.

50. ISO. Ergonomics of the Thermal Environment-Analytical Determination and Interpretation of Thermal Comfort Using Calculation of the PMV and PPD Indices and Local Thermal Comfort Criteria; ISO 7730:2005; International Organization for Standardization: Geneva, Switzerland, 2005.

51. CEN. Energy Performance of Buildings_Ventilation for Buildings_Part 1: Indoor Environmental Input Parameters for Design and Assessment of Energy Performance of Buildings Addressing Indoor Air Quality, Thermal Environment, Lighting and Acoustics-Module M1-6; CEN Standard EN 16798-1:2020; Comité Européen de Normalisation: Brussels, Belgium, 2020.

52. CEN. Energy Performance of Buildings_-Ventilation for Buildings_Part. 2: Interpretation of the Requirements in EN 16798-1-Indoor Environmental Input Parameters for Design and Assessment of Energy Performance of Buildings Addressing Indoor Air Quality, Thermal Environment, Lighting and Acoustics (Module M1-6); CEN Standard EN 16798-2:2019; Comité Européen de Normalisation: Brussels, Belgium, 2019.

53. Alfano, F.D.; Wilkens, O.; Palella, B.I.; Pepe, D.; Riccio, G. Fifty Years of PMV Model: Reliability, Implementation and Design of Software for its Calculation. Atmosphere Z. 2020, 11, 49. [CrossRef] 